\title{
Characterizing and Profiling Global Segments of Responsible Consumers - A Narrative Review
}

\author{
Karnika Gupta \\ Department of Commerce, Kurukshetra University, Haryana. \\ Narendra Singh \\ Department of Commerce, Kurukshetra University, Haryana.
}

\begin{abstract}
The prime purpose of the paper is to examine and identify the determinants of responsible consumption behaviour by synthesizing the determinants' structure as available in varied literature. Further, it profiles responsible consumers according to their identified categories of determinants.

Content analysis is exercised on wide literature of more than one hundred research papers, articles and reports that narrate, characterize and profile responsible consumers.

The identified demography of the responsible consumers includes: females, young, highly educated, academically intelligent, non-business academics, employed in high-status and leadership positions, members of small families and married with children living at home. According to sociological features, responsibles are the children of highly educated parents, get full support from their family, have liberal and democratic political views and hold time and availability to contribute for responsible acts. Viewing from an economic and geographic perspective, these consumers are average in income, satisfied with their income levels, not much wealthier and majority of them lives in urban areas and larger cities. The cultural features support them as collectivists with feeling of universalism. These consumers trust others, open to change, believe in civic-cooperation, like fun, have a network as members of environmental organizations, religious with extreme religiosity and love their country having highest national pride. As far as psychological features are concerned, they originate from a very good psyche, are initiators, internally controlled living indulgent lifestyles, future minded, less sceptic with high civic sense, creative, have harmony and believe in self efficacy. They are also environmentally concerned and settle in balance with nature.
\end{abstract}

The paper will direct marketers in locating and serving the desired segment of responsible consumers. Information on various segmentation dimensions will facilitate easy policy making for STP model and favourable segmentation strategy formulation.

The findings in the paper are based on the results of various studies which may be applicable only on the population similar to sample frame of the individual studies. Future researchers thus get a cue for a more refine research to supplement and enlarge the present inference of responsible consumer segments to disparate markets.

The paper synthesizes vast varied literature for the first time in an evolving field of responsible consumption behavior. The outcome will provide base in theory formulation.

Keywords: Profile, Responsible Consumption Behaviour, Responsible Consumers.

\section{INTRODUCTION}

Today, the world is passing through a critical phase when economic development in its present form seems unsustainable. One of the reasons for this malady is increasing consumption levels that are rapidly depleting the natural resources and creating an ecological imbalance (Uzzell and Rathzel,

Journal of Technology Management for Growing Economies Vol. 8, No. 1 April 2017 pp. 7-39

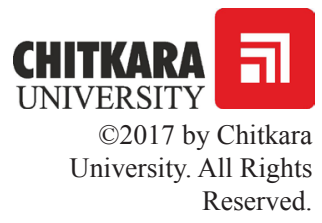


Gupta, K. Singh, N.

2008; Singh, 2009). To overcome this malady, societies across globe are paying renewed attention to the environmental issues (Kaiser et al., 1999). Consumers too as a part of society are expected to perform socially responsible acts in their consumption behaviour (Shanka and Gopalan, 2005; Alibeli and Johnson, 2009). Thus role of every individual as a consumer becomes important for achieving the goal of sustainable development. This fact is not new but investigated by many studies in various field of social sciences as: Anthropology, Psychology, Sociology, Economics, Archaeology, Geography, Social Psychology and Environmental Psychology. Different scholars (Roberts, 1995; Straughan and Roberts, 1999; Laroche et al., 2001; Albayrak et al., 2010) from these disciplines have examined world consumers for their responsibility towards environment protection. Based on different determinant types, their findings contribute several characterstics of such consumers. This paper synthesizes this widespread literature into a relational model to draw synergy from this solitary work; thus enhances the value in this field. This integrated work will guide marketers for the purpose of segmenting their prospective markets for launching environment friendly/green products ${ }^{1}$.

Segmentation of potential markets always helps in increasing consumer satisfaction by encompassing each consumer's expectation and opinion in the segment which benefits consumers, marketers as well as the whole society (Albayrak et al., 2010). To offer these benefits, marketers may be interested in several kinds of information such as: why consumers act in different ways? What factors impel them to act as they do? Or what are the common characterstics of particular consumer groups, etc. For the same, understanding profile of the target consumers is the first task for every marketer to assemble useful segments. This task of profiling itself depends upon the identification of certain consumer characterstics that become the basis of such action. Continuing with this rationale, the prime objective of this paper is to identify the determinants that effect responsible consumption behaviour and construct profiles of a special class of consumers, exclaim as responsible consumers to benefit marketers in the task of segmenting their potential consumer markets. In the theoretical discussions that are presented in the paper, the consumers who perform responsibly are entitled as responsible consumers and their responsible consumption behaviour is defined as a construct in the following section. Also, throughout paper, to compensate for determinants, the expressions: causes, drivers, factors, forces, influencers, predictors and variables are termed as synonymous and are used interchangeably.

\section{RESPONSIBLE CONSUMPTION BEHAVIOUR - CONSTRUCT FOR- MULATION}

According to Peattie (1995), for over 20 years researchers have been trying to identify consumers who can be labeled as environmentally concerned/

Journal of Technology Management for Growing Economies, Volume 8, Number 1, April 2017 
conscious, socially conscious/responsible or green. In the words of Antil (1984) and Ozkan (2009), consumption behaviour of these consumers is spotted differently by academics. There exists multiple identities for explaining this behaviour but all appear to be concerned with the same notions dealing with consumption behaviour in relation to responsibility. Authors have tested this behaviour with slightly different names but the contents and aspects are found quite similar in meaning. In view of this, the identities defining responsibility with consumption behaviour, customary with literature are presented in table 1. As we are moving in the era that is in need of sustainability, the scope of responsibility becomes wider. So, towards present purpose, the construct responsible consumption behaviour is wide enough to admit all the conceptualizations that prevails all over literature and relates consumer consumption patterns with their responsibility towards environment protection and sustainability. It is preferred to call responsible consumption behaviour a construct rather than a concept, because of imprecision and abstractness in the meaning.

Table 1: Responsible Consumption Behaviour Identities from Literature

\begin{tabular}{|l|l|}
\hline Prevailing Identities & Academicians Exercised the Identities \\
\hline $\begin{array}{l}\text { Ecologically Concerned } \\
\text { Consumer Behaviour }\end{array}$ & Kinnear et al. (1974); Schwepker and Cornwell (1991) \\
\hline $\begin{array}{l}\text { Ecologically Conscious } \\
\text { Consumer Behaviour }\end{array}$ & Roberts and Bacon (1997); Tilikidou and Delistavrou (2007) \\
\hline Ecological Behaviour & Kaiser et al. (1999); Kaiser et al. (2003) \\
\hline $\begin{array}{l}\text { Environmental } \\
\text { Behaviour }\end{array}$ & $\begin{array}{l}\text { Tanner (1999); Hunter et al. (2004); Kalantari et al. (2007); } \\
\text { Xiao and Hong (2010) }\end{array}$ \\
\hline $\begin{array}{l}\text { Environmentally Related } \\
\text { Behaviour }\end{array}$ & Bamberg (2005) \\
\hline $\begin{array}{l}\text { Environmentally } \\
\text { Relevant Behaviour }\end{array}$ & Gudgion and Thomas (1991) \\
\hline $\begin{array}{l}\text { Environmentally } \\
\text { Responsible Behaviour }\end{array}$ & $\begin{array}{l}\text { Berger and Corbin (1992); Kaplan (2000); Young (2000); Barr } \\
\text { (2003); Haytko and Matulich (2008) }\end{array}$ \\
\hline $\begin{array}{l}\text { Pro-Environmental } \\
\text { Behaviour }\end{array}$ & $\begin{array}{l}\text { Karp (1996); Clark et al. (2003); Harland et al. (2007); Steg and } \\
\text { Vlek (2009); Chen et al. (2011) }\end{array}$ \\
\hline $\begin{array}{l}\text { Environmentally } \\
\text { Significant Behaviour }\end{array}$ & $\begin{array}{l}\text { Stern (2000); Gatersleben et al. (2002); Stern (2005); Urban } \\
\text { and Zverinova (2009) }\end{array}$ \\
\hline $\begin{array}{l}\text { Environmentally } \\
\text { Supportive Behaviour }\end{array}$ & Kennedy et al. (2009) \\
\hline $\begin{array}{l}\text { Environment Friendly / } \\
\text { Adjusted Behaviour }\end{array}$ & Tindall et al. (2003); Savita and Kumar (2010); Rikner (2010) \\
\hline
\end{tabular}

Journal of Technology Management for Growing Economies, Volume 8, Number 1, April 2017
Characterizing and Profiling Global 


\begin{tabular}{l|l|l|}
$\begin{array}{ll}\text { Gupta, K. } \\
\text { Singh, N. }\end{array}$ & Academicians Exercised the Identities \\
\hline $\begin{array}{l}\text { Environmentally } \\
\text { Sensitive Consumption }\end{array}$ & Alwitt and Pitts (1996) \\
\hline $\begin{array}{l}\text { Environmentally } \\
\text { Sustainable Behaviour }\end{array}$ & Kurz (2002); Dillahunt (2008); Nathaniel (2011) \\
\hline $\begin{array}{l}\text { Behaviour towards } \\
\text { Environment Issues }\end{array}$ & Budak et al. (2005); Muderrisoglu and Altanlar (2011) \\
\hline $\begin{array}{l}\text { Green Purchase } \\
\text { Behaviour }\end{array}$ & Chan (2001); Kim and Choi (2005) \\
\hline $\begin{array}{l}\text { Green Consumption / } \\
\text { Consumer Behaviour }\end{array}$ & $\begin{array}{l}\text { Shrum et al. (1995); Chan (2001); Usui (2001); Gilg et al. } \\
\text { (2005); Ek and Soderholm (2006); Finisterra do Paco and } \\
\text { Raposo (2008); Young et al. (2010); Singh and Gupta (2012) }\end{array}$ \\
\hline $\begin{array}{l}\text { Socially Conscious } \\
\text { Behaviour }\end{array}$ & \begin{tabular}{l} 
Anderson and Cunningham (1972); Webster (1975) \\
\hline $\begin{array}{l}\text { Socially Responsible } \\
\text { Consumption/Consumer } \\
\text { Behaviour }\end{array}$
\end{tabular} & $\begin{array}{l}\text { Antil (1984); Leigh et al. (1988); Roberts (1995); Shanka and } \\
\text { Gopalan (2005); Webb et al. (2008); Oikonomou et al. (2009); } \\
\text { Chen and Kong (2009); Ozkan (2009); Singh (2009); Yuksel } \\
\text { (2009); Lau (2010); Durif et al. (2011) }\end{array}$ \\
\hline $\begin{array}{l}\text { Sustainable } \\
\text { Consumption / } \\
\text { Consumer Behaviour }\end{array}$ & $\begin{array}{l}\text { Tanner and Kast (2003); Haron et al. (2005); Tan and Lau } \\
\text { (2009); Black and Cherrier (2010); Kirachi and Kayabasi } \\
\text { (2010); Young et al. (2010) }\end{array}$ \\
\hline
\end{tabular}

\section{PURPOSE AND OBJECTIVES}

Every day with new research findings, literature is pretended to be divergent because of the use of different terminology and subject backgrounds. The publication of so many determinants of responsible consumption behaviour with varied results have made the structural model of these determinants much complex. So at the outset, it is intended to identify the behavioural determinants from literature and incorporate them under suitable categories. This is followed by analyzing their effect according to which they are profiled further. More specifically, the paper aims at attaining the following objectives.

1. To establish suitable bases for classifying determinants of responsible consumption behaviour.

2. To identify the causal determinants from literature and arrange them under suitable base.

3. To investigate the effect of identified determinants on responsible consumption behaviour.

4. To present profiles of responsible consumers as per conceded effect.

\section{METHODOLOGY}

The paper is based on secondary data to identify forms and patterns that appear in different studies. The theoretical discussions are accompanied with content 
analysis of key events recorded in research papers, articles and different internet websites. Content analysis systematically rearranges the selected portions of literature for the purpose of condensation, the goal of which is to classify words, phrases, or text into meaningful categories that are relevant to research purpose (Wagh, 2010).

\section{ANALYSES AND DISCUSSIONS}

In the two sections, literature is contently analyzed to identify the driving forces of responsible consumption behaviour and their appropriate bases. Then, a narrative review to ascertain the level of effect of identified forces on behaviour is presented. Last section utilizes traditional vote-counting method for profiling responsible consumers as per the profound effect of some determinants on them.

\section{Establishing Suitable Bases - Structure Simplification}

Earlier literature profiled responsible consumers mainly on the basis of demographic determinants but at times other kinds of determinants have also been added to the list. These determinants are visible in literature with divergent terminology. For some instances, Hines et al. (1986/87) examined factors affecting environmental behaviour under three categories: cognitive, psycho-social and demographic. Clark et al. (2003) abridged internal and external as the two broad classes and Kennedy et al. (2009) congregated individual, household and societal categories. Further, Kim and Kim (2010) divided the variables according to social structural approach and social value approach. A comparison of these classifications with each other confirms that the difference rests only in categorization; however, the notions of researchers regarding the variables under different categories intersect with each other. This replication of scholastic work by various authors has made the structure of determinant classification somewhat incomprehensible and reflects a need for some standardization and simplification.

According to Schiffman and Kanuk (1997), consumer behaviour is not an independent subject rather is an interdisciplinary concept. These authors have opined that the factors that affect consumer behaviour originate from diverse study disciplines. As an instance: psychological determinants originate from the study field Psychology and sociological determinants are in use from Sociology and Social Psychology. In light of this fact, the paper identifies a common classification on the basis of traditional subject backgrounds from where researchers have identified determinants of responsible consumption behaviour in literature. Table 2 respond to the first objective and describes these subject backgrounds and determinant classification on the basis of these subjects.

Journal of Technology Management for Growing Economies, Volume 8, Number 1, April 2017
Characterizing and Profiling

Global 
Gupta, K. Singh, N.
Table 2: Interdisciplinary Determinants Approach

\begin{tabular}{|l|l|}
\hline Subjects/Disciplines & Corresponding Determinants and their Measurements \\
\hline $\begin{array}{l}\text { Demography - Statistical } \\
\text { Study of Human Population }\end{array}$ & $\begin{array}{l}\text { Demographic Determinants - These determinants reveal } \\
\text { ongoing trends in demographic composition and have a } \\
\text { profound influence on behaviour. }\end{array}$ \\
\hline $\begin{array}{l}\text { Psychology - Study of Hu- } \\
\text { man Mind }\end{array}$ & $\begin{array}{l}\text { Psychological Determinants - These determinants hold } \\
\text { that individuals do what their heart feels and mind thinks. }\end{array}$ \\
\hline $\begin{array}{l}\text { Sociology/Social Psycholo- } \\
\text { gy - Study of Individuals as } \\
\text { Members of Social Groups }\end{array}$ & $\begin{array}{l}\text { Sociological Determinants - They assume that people } \\
\text { behave differently in different groups and get influenced } \\
\text { by other people. }\end{array}$ \\
\hline $\begin{array}{l}\text { Economics - Study of Al- } \\
\text { location of Individual and } \\
\text { Family Resources }\end{array}$ & $\begin{array}{l}\text { Economic Determinants - Economic determinants work } \\
\text { on the notion that individuals act rationally to maximize } \\
\text { their satisfaction. }\end{array}$ \\
\hline $\begin{array}{l}\text { Archaeology/Cultural An- } \\
\text { thropology - Study of Hu- } \\
\text { man History and Culture }\end{array}$ & $\begin{array}{l}\text { Cultural Determinants - History of man is conclusive that } \\
\text { cultural differences separate one individual from another, } \\
\text { thus affect their behaviour. }\end{array}$ \\
\hline $\begin{array}{l}\text { Geography - Study of } \\
\text { Earth's Physical Character- } \\
\text { stics }\end{array}$ & $\begin{array}{l}\text { Geographical Determinants - As per geographical deter- } \\
\text { minants, behaviour gets affected by the change in physical } \\
\text { characterstics of Earth. }\end{array}$ \\
\hline $\begin{array}{l}\text { Environmental Psychology - } \\
\text { A sub field of psychology, } \\
\text { that studies Human minded- } \\
\text { ness especially for Environ- } \\
\text { ment }\end{array}$ & $\begin{array}{l}\text { Environmental Attitude, Concern and Knowledge - These } \\
\text { variables assert that specific psychic features of human } \\
\text { beings towards environment remarkably predict their en- } \\
\text { vironmentally related behaviour. }\end{array}$ \\
\hline
\end{tabular}

\section{INTEGRATION OF BEHAVIOURAL DETERMINANTS - ARRANGEMENT UNDER PROPER BASE}

The previous section provides a foundation for determinant cataloging and Figure 1 as an answer to the second objective presents the arrangement of causal variables under each determinant category which are further allied in subsequent sections to integrate and profile responsible consumers. However, the defined categories and particular determinant type under each category are only an attempt to simplify the determinant structure and easy understandability of them. This can be a significant notion and virtuous guideline both for marketers and academics for information regarding behavioural determinants; still cannot be stated as a rigid parlance on segmentation dimensions. There always remains flexibility in consumer behaviour research because of lack of any definite scientific practice. 
Figure 1: Integration of Variables under Suitable Base

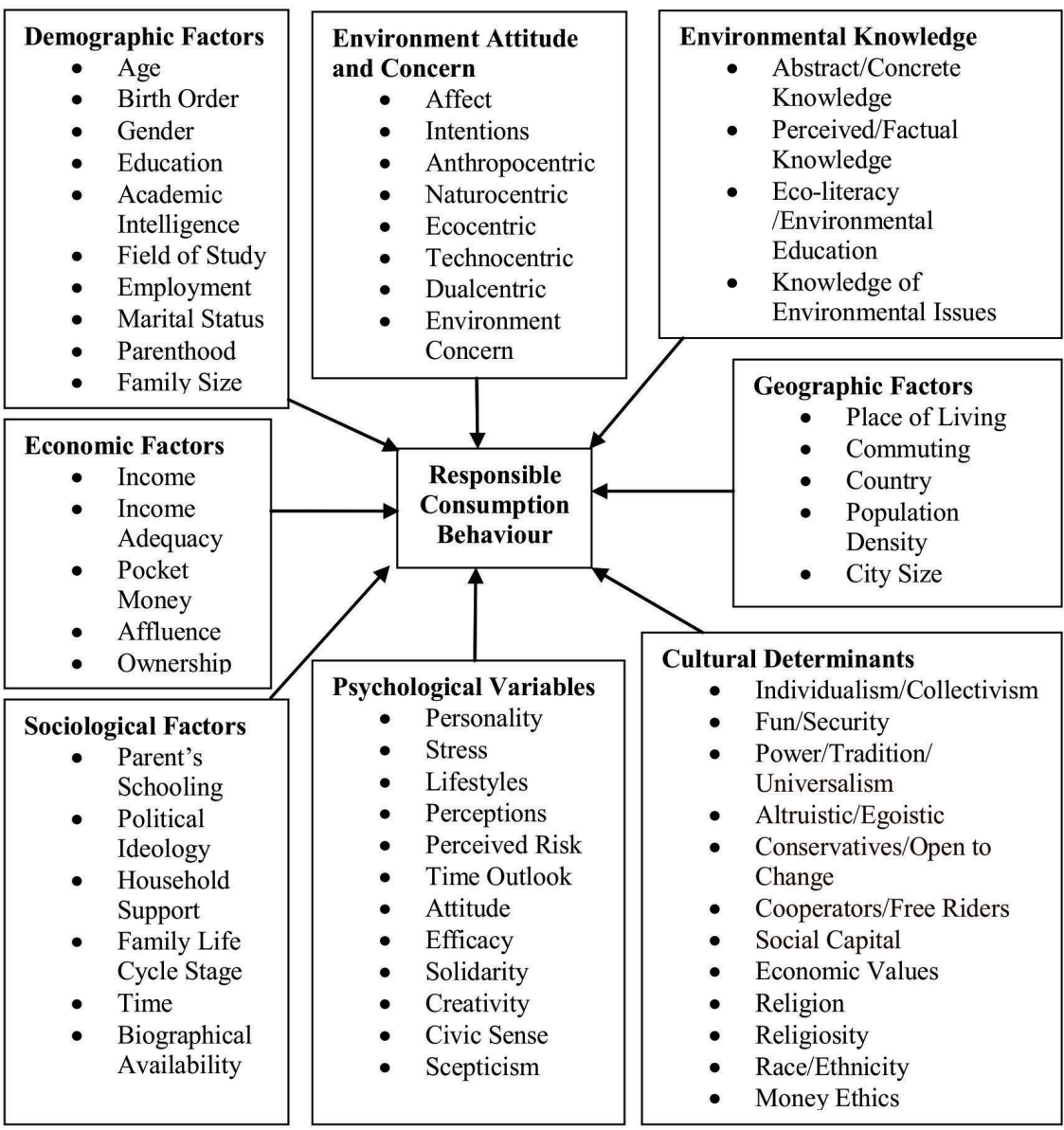

Characterizing and Profiling Global

Source: Structured by Authors

\section{RESPONSIBLE CONSUMPTION BEHAVIOUR - CAUSES AND EF- FECTS}

A particular variable under a specific category may have positive or negative effect on the behaviour. These effects have been studied in literature with various statistical tools and techniques. Here, corresponding to the third objective, the causal results on each variable under a specific category are considered and synthesized in this section.

1). Demographic Determinants: Demography refers to the vital and measurable statistics of population and is most often used in market segmentation 
Gupta, K.

Singh, N.

(Schiffman and Kanuk, 1997). The review of literature supports that demography is the most researched part in this field of study. Works of Crossby et al. (1983); Antil (1984); Roper (1990, 1992); Pickett et al. (1993); Alibeli and Johnson (2009); Singh (2009); Savita and Kumar (2010) and Singh and Gupta (2011) describe relationship of responsible consumption with demographic factors. The findings indicate that age, gender, education, academic intelligence, field of study, occupation, marital status, parenthood and household size are the factors affecting people environmental awareness and shape their efforts for solutions to environment problems.

- Age: According to variable age, younger adults originate as more knowledgeable about climate change, more sensitive to environment issues (McCright, 2010; Straughan and Roberts, 1999) and behave more socially responsibly than their older counterparts (Singh, 2009). On the other hand, studies by Shanka and Gopalan (2005) and Oikonomou et al. (2009) suggest that people turn into conscious about societal aspects as age increases.

- Birth Order: Younger borns significantly report more pro environmental behaviour than later borns, thus birth order very well be an important factor that can contribute to the understanding of why, why not people behave in environment friendly ways (Rikner, 2010).

- Gender: The relationship have been fairly consistent across studies that women are found to favour social-environmental conduct (Straughan and Roberts, 1999; Zelezny et al., 2000; Tindall et al., 2003; Budak et al., 2005; Oikonomou et al., 2009 Alibeli and Johnson, 2009; Lee, 2009; Singh, 2009; Singh and Gupta, 2011) and are ready to pay more for environment friendly products (Laroche et al., 2001). But some studies (Hunter et al., 2004; Xiao and Hong, 2010) also mention that although women are higher in environmental concern but regarding behaviour, they are superior only in private behaviour such as indoor household behaviour; and for public behavioural domain (outside behaviour), men are found with greater activism.

- Education: Many studies (Reizenstein et al., 1974; Laroche et al., 2001; D' Souza, 2005; Tilikidou and Delistavrou, 2007, Alibeli and Johnson, 2009; Urban and Zverinova, 2009; Xiao and Hong, 2010) support that education positively influences green behaviour and educated people are more likely to show this behaviour over less educated. Higher education increases certain behaviours of consumers that are associated with environmental activism; mainly with environmental talk, volunteering and environmental litigation (Chen et al., 2011). Some authors (Shanka and Gopalan, 2005;

Journal of Technology Management for Growing Economies, Volume 8, Number 1, April 2017 
Oikonomou et al., 2009; Singh and Gupta, 2011) also report education as a determinant but with negative effect.

- Academic Intelligence: Consumers' academic intelligence is also a significant determinant of socially responsible behaviour allied with academic qualifications; as direct relationship has been noticed between academic intelligence and attainment of social responsibility by Singh and Gupta (2011).

- Academic Orientation/Field of Study: Tan and Lau (2009) find business students as slightly oriented towards environment in comparison to nonbusiness students. One study (Singh and Gupta, 2011) finds student consumers belonging to humanities act more responsibly instead of those who belong to science background.

- Occupation/Employment: Gupta (2010) obtains working class as more socially responsible than their non working (student) counterparts; and people who are employed full-time are also found more concerned about the environment (McCright, 2010). Some other results enlarge these findings by stating that working respondents those employed in prestigious and leadership positions are environmentally committed and are also engaged in environmental litigation (Chen et al., 2011).

- Marital Status: Chen et al. (2011) find that singles highly participate in behaviours like sort garbage, recycling bags and environmental volunteering; and married people show more concern for the conservation of future resources (Mondejar-Jimenez et al., 2011).

- Parenthood: Parenthood has a profound influence on environmental concern (McCright, 2010). The parents with children living at home are more environmentally concerned than their counterparts (Laroche et al., 2001) but parenthood also clearly reduce levels of participation in environmental behaviour as reflected in a sample of Chinese women (Xiao and Hong, 2010).

- Household/Family Size: Small families show high socially responsible consumption behaviour than medium or large families (Singh and Gupta, 2011).

2). Sociological Factors: Sociological factors indicate behaviour of people when they are operating in a group. These factors can be identified from sociology and social psychology including education of parents, political ideology, stage of family life cycle, household support, time and biographical availability ${ }^{2}$.

- Parent's Education: Father's and Mother's education is studied as a behavioural determinant by Alibeli and Johnson (2009) but the effect is found insignificant. However, according to Taskin (2009), students with well educated and liberal parents and in white-collar professions report

Journal of Technology Management for Growing Economies, Volume 8, Number 1, April 2017
Characterizing and Profiling

Global 
Gupta, K. Singh, N.

more pro-environmental attitudes.

- Political Ideology: Political liberals and democrats in the general public are more knowledgeable about climate change than their politically conservative and republican counterparts (McCright, 2010). Political liberals and those who are more interested in politics are also observed as more proenvironmental (Dietz et al., 1998; Tilikidou and Delistavrou, 2007).

- Household Support: According to the finding by Kennedy et al. (2009), the children living with parents having different habits and routines feel restricted to support green businesses, conserve water or recycle to appease other household members. In this way, the translation of social norms in one's own home influences environmentally supportive behaviour.

- Stage of Family Life Cycle: Anderson and Cunningham (1972) initiate to study stage of family life cycle as a behavioural determinant but this factor fails to significantly discriminate respondents as to the degree of social responsibility.

- Time: As obtained in literature, availability of time can restrict some particular environmental activities. Time may not constraint activities like turning of light and taps but for another environmental behaviours such as activism, taking public transport and recycling; time acts as a direct constraint because of additional time required and usually less time availability with consumers for the same activities (Kennedy et al., 2009).

- Biographical Availability: Tindall et al. (2003) say that biographical availability restraints women's outside environmental activism but their household environment friendly behaviour is not much restricted.

3). Economic Determinants: The economic causes are the indicators of purchasing power of individuals (Tanner and Kast, 2003). The micro economic determinants identified are: income, income adequacy, pocket money, affluence and ownership.

- Income: Studies of Laroche et al. (2001), Alibeli and Johnson (2009) and Singh and Gupta (2011) confirm that middle class express strong support for preservation of environment. However, Tilikidou and Delistavrou (2007) support high class for their environmental behaviour.

- Income Adequacy: According to Ozkan (2009), adequacy of income is consumer's perception about the sufficiency of their income levels. He observes a kind of environmentally unfavourable behaviour of buying heavily packaged products is higher among those consumers who find their incomes inadequate.

- Money/Affluence and Pocket Money: Being wealthier restricts environmentally supportive behaviour such as taking public transport

Journal of Technology Management for Growing Economies, Volume 8, Number 1, April 2017 
instead driving a vehicle (Kennedy et al., 2009). Pocket money as a variable is studied for students as they belong to non earning group. Kirachi and Kayabasi (2010) observe that environmental actions of students significantly get influenced by the level of their pocket money.

- Ownership: Home ownership and automobile ownership is studied as a determinant for driving behaviour. The effect of home ownership is obtained as insignificant (Laroche et al., 2001) but automobile ownership is found significantly related to driving frequency as affirmed by Tanner (1999).

4). Geographical Factors: Geography effects consumer behaviour as people who live in identical geographic conditions have similar needs and wants instead those living in other areas, thus under geographical factors markets are divided by location (Schiffman and Kanuk, 1997). Geographic determinants that attained attention of researchers include commuting ${ }^{3}$, place of living, country and city size.

- Place of Living: Residents of urban areas are found more interested in: recycling bags, environmental volunteering and sorting garbage before disposing it (Chen et al., 2011). However, Singh and Gupta (2011) find rural Indian students as more socially responsible. According to Kirachi and Kayabasi (2010), sustainable consumption behaviour is also exhibited more frequently by students of rural areas or villages. Further rural students too originate as more concerned about environment issues than urban ones (Budak et al., 2005).

- Commuting: Commuting has no noteworthy effect on behaviour. The environment concern and knowledge is found similar among smoky vehicle drivers and private motor vehicle commuters. Train commuters and car commuters are also found identical for their environmental concern (Walton et al., 2004).

- Country: Hunter et al. (2004) while studying consumers of Saudi Arabian countries discern significant differences between them; and Alibeli and Johnson (2009) observe differences between Bahrainis, Qataris and Saudis. Significant differences between Iranians and Indians are noticed by Shobeiri et al. (2006) for their attitude towards environment. In another study, Iranian teachers are observed to be having more favourable environmental attitude than their Indian equivalents (Larijani and Yeshodhara, 2008).

- Population Density: The density of population is found significantly related to the socially responsible consumption behaviour by Antil (1984).

- City Size: City size is studied by Schwepker and Cornwell (1991). The residents of larger cities are found more concerned about pollution and inclined to believe that there are pollution problems.
Characterizing and Profiling

Global

Journal of Technology Management for Growing Economies, Volume 8, Number 1, April 2017 
Gupta, K.

Singh, N.

5). Cultural Factors: Culture determines what is acceptable or unacceptable, important or unimportant, right or wrong and workable or unworkable in a society. It encompasses all learned and shared explicit or tacit assumptions, beliefs, knowledge, norms, values, dress, and language (www.businessdictionary.com). Cultural factors have received academic's attention and consumers who behave in environmentally responsible ways are found influenced by social values (Webster, 1975). Gilg et al. (2005) discuss about two types of values: environmental values and social values. Here, social values are referred and environmental values are termed as a part of environmental attitude and discussed upon later. Social values are studied in literature from many aspects. These aspects are individualism/ collectivism $^{4}$, fun/security, altruistic/egoistic ${ }^{5}$ values, conservatism/open to change and civic cooperation versus free riding. Another type of value; economic value ${ }^{6}$ (materialism and post materialism) is distinguished by a combination of items that refer to the condition of democracy. Values defined by Kim and Kim (2010) are power, tradition and universalism. Other factors seem suitable to cultural category are social capital ${ }^{7}$, religion, religious denominations ${ }^{8}$, religious strength or religiosity ${ }^{9}$, race/ethnicity and money ethics ${ }^{10}$.

- Social Values: Tanner and Kast (2003) establishes individual values as a significant player in determining green consumer behaviour and people with strong social values are seen demonstrating this behaviour highly (Tilikidou and Delistavrou, 2007). Consumers are also found responding to ecologically packaged goods only when such kinds of behaviour become accepted norms in their culture (Schwepker and Cornwell, 1991).

- Individualism/Collectivism: Collectivists tend to be friendlier to environment while individualists are found unfriendly (Triandis, 1993; McCarthy and Shrum, 1994; Kim and Choi, 2005).

- Fun/Security: Fun or enjoyment is positively related to recycling behaviour but security factor is not significantly related to it (McCarthy and Shrum, 1994).

- Power, Tradition and Universalism: Universalism relates positively with environmentalism but Power and tradition are negatively related to it (Karp, 1996; Kim and Kim, 2010).

- Altruistic/Egoistic Values: One category of altruism i.e. social altruism supports pro-environmental behaviour (Straughan and Roberts, 1999; Gilg et al., 2005; Kim and Kim, 2010). Egoism has a negative influence but biospehric altruism is found positively related with green behaviour like willingness to pay (Straughan and Roberts, 1999; Gilg et al., 2005).

Journal of Technology Management for Growing Economies, Volume 8, Number 1, April 2017 
- Conservative/Open to Change: According to Kinnear et al. (1974) and Karp (1996), ecologically concerned consumers are open to new ideas but conservatives are less engaged in green activities and behaviour (Gilg et al., 2005).

- Civic Cooperation/Free Riders: Civic minded individuals are more likely to participate in the goals and efforts of social movements than free riders (Owen and Videras, 2006).

- Social Capital: Among social capital variables; trusting others, membership of environmental organizations and higher national pride significantly correlate with higher willingness to sacrifice for environment purpose (Torgler and Garcia-Valinas, 2007).

- Economic Value: The two economic values (materialism and post materialism) relate closely to environmentalism (Kim and Kim, 2010). Environmentally concerned individuals are more likely to hold non material values (Gilg et al., 2005). Also, post materialism significantly link with petition signing dimension of ecological behaviour (Dietz et al., 1998).

- Religion and Religious Denomination: While elaborating on various religions and their relation to environment, Verma (2009) calls religion as a savior for environment protection. Religious participations are found related with positive behaviour in social matters by Mondejar-Jimenez et al. (2011). Anuar et al. (2012) too mention that religion significantly influence consumer's intention to purchase cause related products (a dimension of socially responsible products). Religious denomination link directly with willingness to sacrifice and sign petition dimensions of environmental behaviour by Dietz et al. (1998) but respondents' having denomination fundamentalists hold less pro-environmental behaviour than other denominations.

- Religiosity/Religious Strength: Religious strength is found not significantly related with pro-environmental behaviour by Dietz et al. (1998). However as per McCright (2010), religious strength or religiosity can affect environmental behaviour indirectly via environmental concern. Kim and Kim (2010) observe variations in environmentalism according to the kind of religion, the degree of conservativeness in religion and strength of religious commitment. Religiosity is also seen impacting consumer's tendency to purchase and use environmentally safe products and a more religious consumer too comes out to be supportive of CSR initiatives of companies that help needy and victims of disasters and avoid buying from those discriminate against minorities (Lau, 2010).
Characterizing and Profiling Global 
Gupta, K.

Singh, N.
- Race/Ethnicity: Whites tended to be more knowledgeable about climate change than their non white counterparts (McCright, 2010) but according to Dietz et al. (1998), blacks report more pro-environmental behaviour, lacking only in sign petitions dimension of this behaviour.

- Money Ethics: The result on money ethics is found insignificant thus the persons who emphasize on money may or may not be supportive of socially responsible consumption (Lau, 2010).

6). Psychological Variables: Psychological characterstics refer to the inner or intrinsic qualities of an individual consumer (Schiffman and Kanuk, 1997). Studies (Schwepker and Cornwell, 1991; Straughan and Roberts, 1999) have mentioned that demographic characterstics are not as important as psychographic in discriminating ecological consumers. Chan (2001) advocates various psychological constructs as important determinants of green and eco friendly consumer behaviour. Personality, a part of psychological variable, defined in terms of locus of contro $1^{11}$ by Schwepker and Cornwell (1991) have notable influence on green buying behaviour. Perceptions in psychological category are studied with $\mathrm{PCE}^{12}, \mathrm{PBC}^{13}$ and perceived risk $^{14}$. Time perspective under it is considered with present, future and past orientations ${ }^{15}$ (Corral-Verdugo et al., 2006). Lifestyles, Scepticism ${ }^{16}$ and solidarity too fall under psychological category (Mondejar-Jimenez et al., 2011). Civic sense ${ }^{17}$, another psychic feature of consumers also significantly affects socially responsible behaviour (Singh and Gupta, 2011).

- Locus of Control/Personality: The consumers with internal locus of control exhibit green buying behaviour but vulnerability has been found in purchasing behaviour of those who have external locus of control (Schwepker and Cornwell, 1991). According to Tilikidou and Delistavrou (2007) those who think they are capable of shaping circumstances rather than being shaped by them are environmentalists, who are ultimately the internally controlled consumers. Also, the authors hold that individuals with greater capacity for initiatives, who lead a healthy life and collaborate in environmental improvements, clearly show ecological behaviour than others.

- Stress: Those who feel stressed for environment protection behave in environment friendly ways (Kalantari et al., 2007).

- Lifestyles: Gilg et al. (2005) have drawn a distinction between those who live an indulgent lifestyle and those who are more frugal. MondejarJimenez et al. (2011) report that people who save energy, water and those who recycle have more similar lifestyles than those of less active people in these acts.

Journal of Technology Management for Growing Economies, Volume 8, Number 1, April 2017 
- Perceived Consumer Effectiveness (PCE): Perceived consumer effectiveness provides greatest insight into ecologically conscious consumer behaviour (Straughan and Roberts, 1999) thus, if perceived consumer effectiveness is higher, so does responsible consumption behaviour (Kim and Choi, 2005; Webb et al., 2008). Other results also confirm that people who rightly perceive pollution problems are also likely to purchase ecologically packaged products (Schwepker and Cornwell, 1991; Gupta, 2010).

- Perceived Behavioural Control (PBC): As stated by Kennedy et al. (2009), perceived control over decisions determines responsible behaviour. Finisterra do Paco and Raposo (2008) find consumers with high perceived behavioural control have more intense environmental behaviours than others.

- Perceived Risk: According to the study by Boivin et al. (2011), the two types of perceived risks; the performance risk and financial risks act as impediments in the purchase of socially responsible goods. Thus restricts responsible consumption of consumers.

- Time Perspective: The effect of time perspective as a variable is noticed on conservation behaviour. Future oriented individuals report a higher engagement in water conservation than present oriented individuals. Opposite of it, past orientation does not affect consumers' conservation effort in significant directions (Corral-Verdugo et al., 2006).

- Attitude: Attitude towards litter and attitude towards ecologically conscious living directly affect ecological purchase intentions of individuals (Balderjahn, 1988; Schwepker and Cornwell, 1991) and optimistic attitude towards green or eco friendly products positively affects the green buying behaviour (Savita and Kumar, 2010).

- Faith in Efficacy and Beliefs: Reported by Laroche et al. (2001), one of the reasons that stop individuals from environmental activities is their understanding of self involvement (self efficacy). Same is observed by Berger and Corbin (1992) that those individuals who believe in the efficacy of others are less engaged in environmental behaviours than those who have faith in their self efficacy.

- Solidarity: The persons with more solidarity or harmony recycle more and also engage themselves in environmental events (Mondejar-Jimenez et al., 2011).

- Creativity: According to Mondejar-Jimenez et al. (2011), creativity is related to willingness to pay behaviour for environment purpose. Creative consumers with a higher intellectual level are observed as more willing to pay extra for ecological products.

- Civic Sense: Consumers with high civic sense are highly socially
Characterizing and Profiling Global 
Gupta, K.

Singh, N. responsible than their low civic counterparts (Singh and Gupta, 2011).

- Scepticism: Albayrak et al. (2010) obtain negative impact of scepticism on green purchase behaviour but the effect is found statistically insignificant.

- Openness to Experience and Agreeableness: Openness to Experience and Agreeableness both relate strongly with greater environmental concern thus, indirectly predict ecological behaviour (Luchs and Mooradian, 2012).

7). Environmental Knowledge: Environmental knowledge refers to the knowledge of the diversity and interactions among plants and animals, landforms, watercourses, and other traits of the biophysical environment (www.en.wikipedia.org). Environmental knowledge also refers to how much an individual knows about environmental issues (Finisterra do Paco and Raposo, 2008) and can be defined as a general knowledge of facts, concepts and relationships concerning the natural environment and its major ecosystem. It also involves what people know about the environment, key relationships leading to environmental aspects or impacts, an appreciation of whole systems and collective responsibilities necessary for sustainable development (Mostafa, 2007). Environment knowledge can also be treated as a kind of informal education (Torgler and Garcia-Valinas, 2007) and includes some other aspects as abstract and concrete knowledge ${ }^{18}$, perceived and factual knowledge, eco-literacy or environmental education and knowledge of environment issues. Authors have also developed scales to measure people environmental knowledge (Kaiser et al., 1999; Laroche et al., 2001).

- General Environmental Knowledge: Knowledge about the impacts that production and consumption can have on environment is established as a driver and a measure of green consumption behaviour by Kaiser et al. (1999) and Tanner and Kast (2003). Some academics (Finisterra and Raposo, 2008; Cavas et al., 2009; Xiao and Hong, 2010) associate knowledge about the environment with environment friendly behaviour. The study by Schwepker and Cornwell (1991) also remarks that increased awareness about solid waste disposal problem result in purchase behaviour change; consequently negative impact on environment can be minimized. Opposite to it, study by Maloney and Ward (1973) report no significant link between environmental knowledge and favourable environmental behaviour.

- Abstract/Concrete Knowledge: Hines et al. (1986/87) reveal abstract knowledge as the most significant type predicting environmental actions.

- Perceived/Factual Knowledge: Mostafa (2007) finds moderate and significant relationship between environmental knowledge and behaviour

Journal of Technology Management for Growing Economies, Volume 8, Number 1, April 2017 
and states that perceived environmental knowledge is the most significant type that influences behaviour.

- Eco-Literacy or Environmental Education: According to Laroche et al. (2001), eco-literacy is not a good predictor of green behaviour but in the words of Gifford et al. (1982), environmental education (environment programs, classes and field experiences) has changed students' attitude and behaviour positively towards environment so, environmental education is a reliable tool in shaping people behaviour that suits the environment.

- Knowledge and Awareness of environment Issues: As per Peattie (1995), actions and decisions of many consumers are increasingly being influenced by environmental issues. Banerjee and Mckeage (1994) recommend that green consumers strongly believe in deteriorating environment conditions and understand problems in security of the world. Kozar (2010) find that individuals who are more knowledgeable about environmental issues and recycling practices are more likely to engage in actual recycling behaviour. Thus awareness of consumers and their knowledge updation regarding environment issues can surely prove a successful tool in solving environment problems as with the knowledge people will try to change themselves in environment friendly ways.

8). Environmental Attitude and Concern: Environmental attitude is considered as being composed of opinions and beliefs toward environment as an object, whereas, environmental concern is the people attentiveness about environmental problems, their support for solving them, willingness to sacrifice and contributions for such attempts (Alibeli and Johnson, 2009). Albayrak et al. (2010) define these two concepts as synonymous. Some studies (Hines et al., 1986/87; Budak et al., 2005; Tilikidou and Delistavrou, 2007) suggest environmental attitude as a moderate predictor of ecological behaviour but Kaiser et al. (1999) attain environmental attitude as its powerful determinant. Thus, environmental attitude is a cause of ecological behaviour as reinforced by above moderate to high relationships. Environmental attitude is studied with various scales having distinct dimensions. According to Maloney and Ward (1973), it is a conglomerate of affect ${ }^{19}$, verbal commitment ${ }^{20}$ and actual commitment. The general measure of environmental attitude is New Environmental Paradigm (NEP) whose components can be traced back in many previous studies. NEP; a fundamentally rational value and general measure of environmental attitude define ultimately the relationship between humans and nature. Previously, NEP factors are extracted by Shetzer et al. (1991) and Roberts and Bacon (1997) as Balance of Nature, Limits
Characterizing and Profiling

Global

Journal of Technology Management for Growing Economies, Volume 8, Number 1, April 2017 
Gupta, K.

Singh, N.

to Growth and Man over Nature (Adoption before Modification, God and Nature). However, recently NEP is also shown reflecting Anthropocentric ${ }^{21}$, Naturocentric ${ }^{22}$, Ecocentric ${ }^{23}$, Technocentric and Dualcentric ${ }^{24}$ views (Kim and Kim, 2010; Muderrisoglu and Altanlar, 2011). The names given to these factors are different but they symbolize Balance of Nature, Limits to Growth and Man over Nature as the earlier extracted factors of NEP.

- Environmental Affect: Consistent with Maloney and Ward (1973) there is a positive relationship between environmental affect and environmental behaviour but Chan (1999) believe that consumer actions for environment protection is low instead they showed very high environmental affect.

- Verbal commitments/Intentions to Behave: Maloney and Ward (1973) observe that although environmental affect relates significantly with environmental behaviour but the actions for safeguarding of environment get highly influenced by their intentions to behave environmentally.

- Anthropocentric Attitude/Domination and Fragility Beliefs: Domination beliefs are negatively related to ecological adjustments and positively to uncaring behaviour (Singh and Gupta, 2013). Anthropocentric and domination beliefs thus have negative impact on environmental behaviour (Kim and Kim, 2010).

- Naturocentric Views: The people with naturocentric views are found eager and ready to work for environment protection (Kim and Kim, 2010).

- Ecocentric views or Concern for Nature: Gilg et al. (2005); Muderrisoglu and Altanlar (2011) and Singh and Gupta (2013) demonstrate that concern for nature is positively related to and significantly predict ecological behaviour.

- Technocentric views or Limits to Growth: Studies (Gilg et al., 2005; Singh and Gupta, 2013) are consistent that people beliefs regarding limits to societal expansion and critical level of biological situations highly determine ecological behaviour.

- Environment Concern: Vining and Ebreo (1992) locate that environmental concern is predictive of green consumption. Roberts (1996) also come across that respondents with environmental concern behave more consciously in their consumption response to minimize negative impact on environment.

The above points corroborate that there exists a range of factors, which effect and determine responsible consumption behaviour. Among these factors the common consumer characterstics are noted and profiles of responsible consumers are prepared in the following section.

\section{PROFILE OF RESPONSIBLE CONSUMERS - SEGMENTATION AP- PROACH}

According to different responsible consumption concepts that are appearing in literature (as shown in Table 1) such consumers have been identified by different

Journal of Technology Management for Growing Economies, Volume 8, Number 1, April 2017 
names. Some authors prefer to call them as green consumers; environmentally responsible consumers; environmentally-ecologically conscious consumers; environmentally-ecologically concerned consumers; ecological consumers or environmentally supportive consumers. On the other hand, these consumers are also opined as socially responsible consumers, socially conscious consumers and sustainable consumers. Throughout literature, these terms are interchangeably used with almost similar meanings. To the present purpose, we prefer to call these consumers as responsible consumers. As the construct responsible consumption behaviour is broadly defined, the word responsible seems appropriate for them and can cover all differing consumer identities mentioned above.

It has already been discussed that these consumers may have different characterstics based on various categories of determinants. Demographic determinants gave them some demographic characterstics and on the basis of psychological determinants they seem to possess certain psychological features. Here, for profiling consumers according to their different characterstics, traditional vote-counting method is used which is defined with three possible outcomes for the relationship between an independent and dependent variable. The relationship between independent and dependent variable can be either significantly positive, significantly negative or there can be no relationship in either direction (Pal and Davar, 2001). Under this method, the number of results for each determinant category is simply tailored and the plurality of results that fall into particular category is noted. Then, the model class is declared winner with maximum results. Consistent with this, profiling of responsible consumers is completed here with the same method. However, the method may have several limitations but as the existing data is theoretical in nature, there is no other option for profiling consumers to achieve the last objective and construct segmentation dimensions.

1). Demographic determinants and consumers profile: The demographic findings range from equivocal to contradictory and the basic image of responsible consumers emerging from demographic determinants is that of women, educated, academically intelligent, from non-business study subjects, employed in prominent and leadership positions, married with children living at home and those belonging to small sized families. Younger adults are higher environment oriented and older are conscious about the societal aspects. Gender, education, field of study, employment, parenthood and family size come out as the consistent determinants among all.

2). Consumer's profile according to sociological determinants: As established by sociological determinants the type of consumers must have
Characterizing and Profiling Global 
Gupta, K. Singh, N.

full household support for showing responsible acts in their consumption behaviour. The children of highly educated parents, interested in politics having democratic and liberal political views are found to be more responsible. Busy schedules, less time and individual's unavailability for specific acts may restrict socially desirable actions thus, the responsible kinds of consumers are those who have sufficient time to think about their past deleterious behaviour and adjust accordingly. According to demographic features, married are responsibles but being a parent also reduce the activism for environmental purpose, especially for women.

3). Profiling as per economic factors: Economic determinants attempt to categorize responsible consumers according to their income, income adequacy, affluence and ownership. In relation to these, responsible consumers have no possession of automobiles. Automobile ownership leads to greater driving frequency which is an anti-environmental behaviour and trigger pollution problem. Responsible consumers are also not wealthier and come under middle class category. They are financially satisfied thinking that their incomes are adequate.

4). Profiling according to geographical determinants: Geographical determinants provide consumers with geographical characterstics. The level of responsible behaviour may differ according to countries in which consumer resides. They are typically those who come from larger cities and urban living places, however some results also favour rural residents for their socially responsible behaviour but these results particularly relates to developing world. Some consumers for their particular purposes commute from one place to another but the use of vehicle for commuting has no significant effect on environmental behaviour. About the mode of commuting, people are not much sensible from environmental aspects; their priority is only to reach at the destination on time.

5). Culture and responsible consumer segments: The field is consistent that consumers differ according to cultural values and norms they are brought up with. The cultural features support that individuals who are collectivists, have feelings of universalism and like fun-enjoyment play significant roles for protection of environment. Responsible people trust others, believe in civic cooperation, open to change and have a network as members of environmental organizations. They also love their country and have highest national pride. The altruistic and biospheric values of their culture teaches them concern for others and environment. Thus, those who are conservative, materialistic, count money ethics and have egoistic values are simply out of responsible category. Responsibles also tend to

Journal of Technology Management for Growing Economies, Volume 8, Number 1, April 2017 
be religious with extreme religiosity construing that nature is the reflection of God on Earth. Race can also determine responsible behaviours but segmentation as per racial group is in controversy, as the variable is less studied in literature.

6). Psychology and responsible consumer segments: The psychological characterstics suggest that the responsible kind of consumers are generally more internally controlled and live indulgent lifestyles. The group is formed with those who are initiators, creative, strongly believe in self efficacy, have more solidarity in their personality, future oriented, stressed about the environment and controlled in their behaviour. They rightly perceive environmental problems and understand that their own participations for environment protection can make big differences. They are also less sceptic in nature, have high civic sense, positive attitude towards environment protection and conscious about healthy living which is only possible in a healthy living environment. Thus, these consumers are different from others because they have very good psyche to analyze that the goodness is in their own hands. It will be safe and beneficial to alter one's own actions to suit the environment instead of blaming others.

7). Environmental knowledge and responsible consumers: It is a part of consumer's responsibility that they should try to be knowledgeable about environment matters. Thus, these consumers possess more environmental knowledge and are aware and conscious about environmental issues. Among the types of environment knowledge, responsible consumers are likely to have abstract, perceived knowledge and a strong belief that environment is deteriorating day by day which can create problems in sustainable living. The people who get knowledge about complicated environment structure also form a part in responsible category.

8). Environmental viewpoints and profile of responsibles: Consumer positive attitude and concern towards environment make them fall in the category of responsible consumers. The consumers who base their behaviour on environmental theme are emotionally attached, concerned and conscious about the environment. The highly responsibles for the environment are those who are ready to convert their affect and noble intentions in actual ecological actions. Highly concerned individuals believe that their irrational actions can impact environment negatively and can hamper their own survival on Earth. Those who perceive critical biological situations and understand the limits to societal and industrial growth also get a place among responsibles. Therefore, they are not those who are dominated over nature, believe in man's sovereignty on it; are
Characterizing and Profiling Global 
Gupta, K.

Singh, N.

insensitive and intolerant.

This overall discussion profile responsible consumers across different dimensions and among these various aspects, useful segments can be worked upon for the purpose of segmentation. Acquiring the central theme of the paper, on the basis of demographic and geographic profile, there can be demographic or geographic segmentation; likewise psychographic segmentation can be obtained according to psychological profile of consumers and similarly others. If marketers require, they may also obtain some hybrid form of segmentation as socio-cultural, socio-economic or socio-psychological or similar combinations.

\section{CONCLUSION}

This paper contently analyzed the literature and uniquely elaborated on all possible determinants that have been seen influencing responsible consumption behaviour. Taken as a whole, a wide range of research point up the special class of responsible consumers and separate them from the general public. The profiling of consumers on the basis of effect of particular determinant will be all together appropriate and one can get hunches about the causal relationship between the determinants and responsible consumption behaviour. Content analysis provides evidence for the unique features of responsible consumers which are: highly educated, non-business academics, women, academically intelligent, working on high-status and leadership positions, married with children living at home, members of small families, young, children of highly educated parents, interested in politics having democratic and liberal political views, not much wealthier, financially satisfied, urban residents and have values like collectivism, fun and trust. They are also open to change, civic minded, religious with extreme religiosity, initiators, internally controlled living indulgent lifestyles, creative, believe in self-efficacy, have harmony, future minded, less sceptic with high civic sense, environmentally knowledgeable, concerned for environment and settle in balance with nature. In the light of these findings the paper offers some implications and directions for further research.

\section{MARKETING IMPLICATIONS}

The study will guide marketers in identifying and serving the desired segment of responsible consumers. Any marketer may obtain different kind of responses from consumers regarding purchase of green products. At a point of time, some consumers may perhaps buy energy efficient products and at the same time the products made of recycled material are denied. The latter case brings no immediate benefits (such as reduction in electricity bills in the

Journal of Technology Management for Growing Economies, Volume 8, Number 1, April 2017 
former case) to consumers and they can also perceive that the products made of recycled material are of lower quality. In both the conditions, different kind of promotional techniques will have to be considered as consumers need different motivations and buying stimulus. Marketers in this way require suitable appeal for encouraging consumer outcomes regarding purchase of both types of products by considering various psychological and environmental attributes of consumers. Information on various segmentation dimensions will also facilitate marketers for easily inventing policies meant for their STP model (segmenting, targeting, positioning) and favourable segmentation strategy formulation i.e. for concentrated marketing, differentiated marketing and niche marketing.

\section{LIMITATIONS AND FUTURE RESEARCH}

The past studies on responsible consumers and responsible consumption behaviour were fragmented due to copious terminology and backgrounds. This paper integrates and synergies the literature thus provides a platform to further develop this subject. Segmentation, which otherwise is a challenge as well an opportunity can be benefited by integrating the influencing variables into a causal model that provide practical and sufficient information to marketers for simplify the determinant structure. The paper targeted market segmentation on the basis of specific consumer characterstics; although product attributes also play an important role. Practically, segmentation may be a combination of these different consumer accreditations in consideration with the nature of product. Further research, in turn, can respond the preferred answers to marketers by assimilating the both kind of information. Also, certain results may relate only with some particular consumer markets. Hence, only a more refine research can supplement and enlarge the present conclusion to disparate markets.

\section{ENDNOTES}

1 Green product is a product that is environmentally preferable relative to comparable products (www.ecolabelindex.com). According to one more definition green products have less impact on the environment and are less detrimental to human health. Green products might, typically, be formed or part-formed from recycled components, be manufactured in a more energy-conservative way, or be supplied to the market with less packaging or all three (www.enviro-news.com).

2 According to Xiao and Hong (2010), biographical availability refers to individuals' abilities to participate in environmental activities which may be potentially constrained by their disposable time and shaped by other roles and duties.

Journal of Technology Management for Growing Economies, Volume 8, Number 1, April 2017
Characterizing and Profiling

Global 
Gupta, K.

Singh, N.

3 Commuting as a special feature of consumers is studied by Walton et al. (2004). Private motor vehicle commuters, smoky vehicle commuters, train commuters and bus commuters are studied for their environmental concern and knowledge.

4 Kim and Choi (2005) define that Individualism is characterized by independence, self-reliance, freedom of choice and high level of competition while collectivism emphasizes interdependence, in-group harmony, family security, group oriented goals, social hierarchies, cooperation and low level of competition. According to them, in literature, idiocentrism is synonym of individualism and allocentrism is equal to collectivism.

5 Altruism is a conglomerate of two kinds: social altruism and biospehric altruism. Social altruism is concern for the welfare of others and biospehric means concern for non human elements of environment (Straughan and Roberts, 1999; Gilg et al., 2005). According to Gilg et al. (2005) social altruism means pro-social and egoistic means pro self value and as per Usui et al. (2003) altruism includes social justice, world at peace and equality; egoistic values on the other hand include wealth and authority.

6 Economic values are defined as materialism and post materialism in literature. Post materialism in economic value is giving the people more say in important government decisions and protecting freedom of speech. For materialism it means maintaining order and fighting rising prices (Kim and Kim, 2010).

7 Torgler and Garcia-Valinas (2007) offer the concept of social capital in this study area. The three concepts that are included in social capital are trust, cooperation and network. Most people build trust, network to others and then come to cooperate with them.

8 Religious denominations in literature are taken as Fundamentalists, Moderate Protestant, Liberal Protestant, Catholic and no affiliation to any religion (Dietz et al., 1998).

9 Religiosity is the extent to which an individual is committed to the religion he or she professes and the faith in the teachings of such religion (Lau, 2010).

10 Lau (2010) states that money at individual level, is the most meaningful object in modern life. According to their culture, people themselves develop some values and ethics related to money which is named as money ethics. Money ethics are stated as an evil and a root cause of all ills because of people preference and love for money over environment. In literature a scale named money ethics scale (MES) is developed to measure ethical meanings that people ascribe to money.

Journal of Technology Management for Growing Economies, Volume 8, Number 1, April 2017 
11 Locus of control refers to the reinforcement of selfbehaviour by individuals. People who believe that they can control the events and consequences that affect them are said to possess internal locus of control. On the other hand those who believe that outcomes are the results of circumstances and fate which are beyond their control are said to have external locus of control (Schwepker and Cornwell, 1991).

12 Perceived consumer effectiveness is referred to as the belief that an individual have regarding their favourable influence on solving social and environmental problems (Webb et al., 2008). According to Ozkan (2009), PCE is the recognition of the effectiveness of consumers. He explained the concept with individual's belief in primarily the existence of a problem related to the environment and then their ability to contribute for the solution of this problem.

13 Perceived behavioural control reflect the extent to which the consumers believe that their participations may be effective in the preservation of the environment and they can control their behaviour according to circumstances (Finisterra do Paco and Raposo, 2008).

14 Perceived risk is studied with five components: psychological risk, temporal risk, performance risk, physical risk and financial risk. Psychological risk is about choosing a bad product which could have a negative impact on the consumer's ego. Temporal risk is associated with the time wasted in shopping around for socially responsible goods. Performance risk involves the risk in purchasing of goods which do not work as they should. Physical risk is related to the impact of socially responsible goods on one's health. Financial risk is the measured risk of paying a high price for socially responsible goods relative to comparable goods (Boivin et al., 2011).

15 Future orientation is something that compels individuals to anticipate consequences of their own behaviour. Present orientation makes people prone to enjoying the immediate use of natural resources and past behaviour is related with having a pleasant or painful past experiences (Corral-Verdugo et al., 2006).

16 Scepticism is a psychological concept examined by advertisement related studies in marketing and identified as the tendency of disbelief the consumer has towards green claims of marketers. Psychology suggests that a sceptic person doubts about other people's expressions or attitudes, however the kind of people can be persuaded by presenting some evidences (Albayrak et al., 2010).

17 Civic Sense is nothing but social ethics which are the investigation into the basic concepts and fundamental principles of human conduct. People consideration for the unspoken norms of the society makes their civic
Characterizing and Profiling Global

Journal of Technology Management for Growing Economies, Volume 8, Number 1, April 2017 
Gupta, K.

Singh, N. sense (Singh and Gupta, 2011).

18 Schahn and Holzer (1990) elaborate on abstract and concrete as the two distinguished knowledge aspects. The former relates to knowledge concerning environment issues, problems, causes, solutions and the later relates to behavioral knowledge that can be utilized and acted upon.

19 Environmental affect means the degree of emotionality that an individual displays in relation to environmental issues (Chan, 1999).

20 Verbal commitment means consumer's preparedness to do something for the environment. It simply means that environmental affect which will go to convert into behavioural intentions (Chan, 1999).

21 Anthropocentrism is defined as a faith that nature is regarded as a means to satisfy the human needs and as objects to obey human orders (Kim and Kim, 2010). According to Uitto et al. (2004), it reveals a utilitarian and rational attitude towards the value of natural environment.

22 Naturocentric factor is composed of items which emphasize the concept of sancity of nature and that humans generally have a rather destructive impact on the environment. Its subject matter highlights animal rights and is skeptical about the ability of science and technology to solve environment problems (Muderrisoglu and Altanlar, 2011).

23 Ecocentric view captures that environment is in a precarious position and the impact of humans can be detrimental to survival of mankind (Muderrisoglu and Altanlar, 2011). This factor is also shown as balance of nature and concern for nature attitude and is found positively correlated with ecological behaviour (Roberts and Bacon, 1997; Singh and Gupta, 2013).

24 Technocentric views represent that technology can be used for the solutions of environment problems and for coping with them. Dualcentric views on the other hand, indicates a symbolic relationship between human and other living things (Muderrisoglu and Altanlar, 2011).

\section{REFERENCES}

Albayrak, Tehir; Caber, Meltem and Aksoy, Safak (2010), "Clustering Consumers According to Their Environmental Concerns and Skepticisms", International Journal of Trade, Economics and Finance, Vol. 1, No. 1, pp. $84-88$.

Alibeli, Madalla A. and Johnson, Chris (2009), "Environmental Concern: A Cross National Analysis", Journal of International and Cross-Cultural Studies, Vol. 3, Issue 1, pp. $1-8$.

Alwitt, Linda F. and Pitts, Robert E. (1996), "Predicting Purchase Intentions for an Environmentally Sensitive Product", Journal of Consumer Psychology, 5(1), pp. 49 - 64. http://dx.doi.org/10.1207/s15327663jcp0501_03.

Anderson, W. Thomas Jr. and Cunningham, William H. (1972), "The Socially Conscious Consumer", Journal of Marketing, Vol. 36, pp. 23 - 31.

Antil (1984); Antil and Bennett (1979), "Socially Responsible Consumption Behaviour: SRCB" in Bearden, Williom O and Richard G Netemeyer (Ed.), (1993), Handbook of Marketing

Journal of Technology Management for Growing Economies, Volume 8, Number 1, April 2017 
Scales: Multi-Item Measures for Marketing and Consumers, Sage Publications, New Delhi, pp. $100-102$.

Anuar, Marhana Mohamed; Adam, Fadzli and Omar, Khatijah (2012), "The Role of Religiosity in Socially Responsible Consumption", International Journal of Asian Social Science, 2(9), pp. $1467-1476$.

Balderjahn, I. (1988), "Personality Variables and Environmental Attitudes as Predictors of Ecologically Responsible Consumption Patterns", Journal of Business Research, 17, pp. 51 - 56. http://dx.doi.org/10.1016/0148-2963(88)90022-7.

Bamberg, Sebastian(2005), "How DoesEnvironmentalConcern Influence SpecificEnvironmentally Related Behaviors? A New Answer to an Old Question", Journal of Environmental Psychology, 23, pp. 21 - 32. https://dx.doi.org/10.1016/S0272-4944(02)00078-6

Banerjee, B \& McKeage, K (1994), "How Green Is My Value: Exploring the Relationship Between Environmentalism and Materialism", in CT Allen \& RR John (Eds), Advances in Consumer Research, Association for Consumer Research, Provo, UT, vol. 21, pp. 147 -152 .

Barr, Stewart (2003), "Strategies for Sustainability: Citizens and Responsible Environmental Behaviour", Royal Geographical Society (With the Institute of British Geographers), 35, 3, pp. 227 - 240. https://dx.doi.org/10.1111/1475-4762.00172.

Berger, Ida E. and Corbin, Ruth M. (1992), "Perceived Consumer Effectiveness and Faith in Others as Moderators of Environmentally Responsible Behaviors", Journal of Public Policy and Marketing, Vol. 11(2), pp. 79 - 89.

Black, Iain R. and Cherrier, Helene (2010), "Anti-Consumption as Part of Living a Sustainable Lifestyle: Daily Practices, Contextual Motivations and Subjective Values", Journal of Consumer Behaviour, 9, pp. 437 - 453. https://dx.doi.org/10.1002/cb.337.

Boivin, Caroline, Duff, Fabien and Roy, Jean (2011), "Buying Socially Responsible goods: The Influence of Perceived Risks Revisited, World Review of Business Research, Vol. 1(4), pp. 191-201.

Budak, Dilek Boston; Budak, Fuat; Zailnaglu, Zeynep; Kekee, Secil and Sucu, M. Yavuz (2005), "Behaviour and Attitudes of Students towards Environmental Issues at Faculty of Agriculture, Turkey", Journal of Applied Sciences, 5(7), pp. 1224 - 1227. https://dx.doi. org/10.3923/jas.2005.1224.1227.

Cavas, Bulent; Cavas, Pinar; Tekkaya, Ceren; Cakiroglu, Jale and Kesercioglu, Teoman (2009), “Turkish Students' Views on Environmental Challenges with Respect to Gender: An Analysis of ROSE Data", Science Education International, Vol. 20, No.1/2, pp. 69 - 78.

Chan, K. (1999), "Market segmentation of Green Consumers in Hong Kong", Journal of International Consumer Marketing, Vol. 12, No. 2, pp. 7 - 24. http://dx.doi.org/10.1300/ J046v12n02 02.

Chan, Ricky Y. K. (2001), “Determinants of Chinese Consumers' Green Purchase Behavior”, Psychology and Marketing, Vol. 18(4), pp. $389-413$.

Chen, Hua and Kong, Yusheng (2009), "Chinese Consumer Perceptions of Socially Responsible Consumption”, Social Responsibility Journal, Vol. 5, No. 2, pp. 144 - 151. http://dx.doi. org/10.1108/17471110910964441.

Chen, Xiaodong; Peterson, M. Nils; Hull, Vanessa; Lu, Chuntian; Lee, Graise D., Hong, Dayong and Liu, Jianguo (2011), "Effects of Attitudinal and Socio Demographic Factors on Proenvironmental Behaviour in Urban China”, Environmental Conservation, pp. 1 - 8. https:// dx.doi.org/10.1017/S037689291000086X.

Clark, Christopher F., Kotchen, Matthew J. and Moore, Michael R. (2003), "Internal and External Influences on Pro-Environmental Behavior: Participation in a Green Electricity Program", Journal of Environmental Psychology, 23, pp. 237 - 246. https://dx.doi. org/10.1016/S0272-4944(02)00105-6.

Corral-Verdugo, Victor and Sing, Blanca Fraijo (2006), "Sustainable Behavior and Time Perspective: Present, Past, and Future Orientations and Their Relationship with Water Conservation 
Gupta, K.

Singh, N.
Behavior", Inter American Journal of Psychology, Vol. 40, No. 2, pp. 139 - 147.

Crossby, Lawrence A., James, D. Gill and James, R. Taylor (1983), "Psychological Commitment and Its Effects on Post Decision Evaluation and Preference Stability among Voters", Journal of Consumer Research, Vol. 9, pp. 413 - 431. https://dx.doi.org/10.1086/208935.

D'Souza, Clare (2005), "Proactive Environmentalism: An Examination of the Australian Consumer Market”, Electronic Green Journal, UCLA Library, UC Los Angeles, Issue 22, pp. 1 - 15. http://egj.lib.uidaho.edu/egj22/dsouza1.html.

Dietz, Thomas; Stern, Paul C. and Guagnano, Gregory A. (1998), "Social Structure and Social Psychological Bases of Environmental Concern”, Environment and Behaviour, Vol. 30, No. 4, pp. 450 - 471. https://dx.doi.org/10.1177/001391659803000402.

Dillahunt, T., Becker, G., Mankoff, J. and Kraut, R. (2008), "Motivating Environmentally Sustainable Behavior Changes with a Virtual Polar Bear", Persuasive Technology and Environmental Sustainability.

http://www.cs.cmu.edu/afs/cs.cmu.edu/Web/People/tdillahu/Site/Research_files/Polar\%20 Bear.pdf.

Durif, F., Boivin, C., Rajaobelina, L. and A. Francois-Lecompte (2011), "Socially Responsible Consumers: Profile and Implications for Marketing Strategy", Proceedings at the 14th International Business Research Conference, Dubai, UAE, April, pp. 28 - 30.

http://www.bizresearchpapers.com/14.\%20Fabien.pdf.

Ek, Kristina and Soderholm, Patrik (2006), "Green Electricity Consumption in Swedish Households: The Role of Norm-Motivated Consumer Behavior", SHARP Research Programme, Working Paper 5, pp. $1-32$.

Finisterra do Paco, Arminda M. and Raposo, Mario Lino Barata (2008), "Determining the Characteristics to Profile the "Green" Consumer: An Exploratory Approach", International Review on Public and Nonprofit Marketing, 5, pp. 129 - 140. https://dx.doi.org/10.1007/ s12208-008-0010-9.

Gatersleben, Birgitta; Steg, Linda and Vlek, Charles (2002), "Measurement and Determinants of Environmentally Significant Consumer Behavior", Environment and Behavior, Vol. 34, No. 3, pp. $335-362$.

Gifford, Robert; Hay, Robert and Boros, Karen (1982), "Individual Differences in Environmental Attitudes", Journal of Environmental Education, Vol. 14, No. 2, pp. 19 - 23, Win $1982-$ 83. http://dx.doi.org/10.1080/00958964.1983.10801933.

Gilg Andrew; Barr, Stewart and Ford, Nicholas (2005), "Green Consumption or Sustainable Lifestyles? Identifying the Sustainable Consumer”, Futures, 37, pp. 481 - 504. https:// dx.doi.org/10.1016/j.futures.2004.10.016,

Gudgion, T. J., Thomas, M. Pugh. (1991), "Changing Environmentally Relevant Behaviour", Environmental Education and Information, 10(2), 101-12.

Gupta, Karnika (2010), "Consumer Social Responsibility - Attitude towards Environment Protection", M. Phil Dissertation (unpublished), Kurukshetra University, Kurukshetra, Haryana, India.

Harland, Paul; Staats, Henk and Wilke, Henk A. M. (2007), "Situational and Personality Factors as Direct or Personal Norm Mediated Predictors of Pro-Environmental Behavior: Questions Derived From Norm-Activation Theory", Basic and Applied Social Psychology, 29(4), pp. 323 - 334. http://dx.doi.org/10.1080/01973530701665058.

Haron, Sharifah A., Paim, Lally and Yahaya, Nurizan (2005), "Towards Sustainable Consumption: An Examination of Environmental Knowledge among Malaysians", International Journal of Consumer Studies, 29, 5, pp. 426 - 436. http://dx.doi.org/10.1111/ j.1470-6431.2005.00460.x.

Haytko, Diana L. and Matulich, Erika (2008), "Green Advertising and Environmentally Responsible Consumer Behaviours: Linkages Examined", Journal of Management and Marketing Research, Vol. 1, pp. $1-11$.

Hines, J. M., Hungerford, H. R. and Tomera, A. N. (1986/87), “Analysis and Synthesis of Research

Journal of Technology Management for Growing Economies, Volume 8, Number 1, April 2017 
on Responsible Environmental Behavior: A Meta-Analysis", Journal of Environmental Education, 18(2), pp. 1 - 8. http://dx.doi.org/10.1080/00958964.1987.9943482.

Hunter, Lori M., Hatch, Alison and Johnson, Aaron (2004), "Cross-National Gender Variation in Environmental Behaviors", Social Science Quarterly, Vol. 85, No. 3, pp. 677 - 694. http:// dx.doi.org/10.1111/j.0038-4941.2004.00239.x.

Kaiser, Florian G., Doka, Gabor; Hofstetter, Patrick and Ranney, Michael A. (2003), "Ecological Behavior and Its Environmental Consequences: A Life Cycle Assessment of a SelfReport Measure", Journal of Environmental Psychology, 23, pp 11 - 20. https://dx.doi. org/10.1016/S0272-4944(02)00075-0.

Kaiser, Florian G., Ranney, Michael; Hartig, Terry and Bowler, Peter A. (1999), "Ecological Behavior, Environmental Attitude, and Feelings of Responsibility for the Environment", European Psychologist, Vol. 4, No. 2, pp. 59 - 74. http://dx.doi.org/10.1027//1016-9040.4.2.59.

Kalantari, Khalil; Fami, Hossein Shabanali; Asadi, Ali and Mohammadi, H. Movahed (2007), "Investigating Factors Affecting Environmental Behavior of Urban Residents: A Case Study in Tehran City-Iran", American Journal of Environmental Sciences, 3 (2), pp. 67 - 74. https:// dx.doi.org/10.3844/ajessp.2007.67.74.

Kaplan, Stephen (2000), "Human Nature and Environmentally Responsible Behavior", Journal of Social Issues, Vol. 56, No. 3, pp. $491-508$.

Karp, David Gutierrez (1996), "Values and Their Effect on Pro-Environmental Behavior", Environment and Behavior, Vol. 28, No. 1, pp. 111 - 133. https://dx.doi. org/10.1177/0013916596281006.

Kennedy, Emily Huddart; Beckley, Thomas M., McFarlane, Bonita L. and Nadeau, Solange (2009), "Why We Don't "Walk the Talk": Understanding the Environmental Values/ Behaviour Gap in Canada", Human Ecology Review, Vol. 16, No. 2, pp. 151 - 160.

Kim, Seoyong and Kim, Sungwook (2010), "Comparative Studies of Environmental Attitude and Its Determinants in Three East Asia Countries: Korea, Japan, and China", International Review of Public Administration, Vol. 15, No. 1, pp. 17 - 33. http://dx.doi.org/10.1080/12 294659.2010.10805164.

Kim, Yeonshin and Choi, Sejung Marina Choi (2005), “Antecedents of Green Purchase Behavior: An Examination of Collectivism, Environmental Concern, and PCE", Advances in Consumer Research, Vol. 32, pp. $592-599$.

Kinnear, Thomas C., Taylor, James R. and Ahmed, Sadurdin A. (1974), "Ecologically Concerned Consumers: Who Are They?" Journal of Marketing, Vol. 38, pp. 20 - 24. http://dx.doi. org/10.2307/1250192.

Kiraci, Hakan and Kayabasi, Aydin (2010), "Real and Spurious Sustainable Consumption Behavior in Turkey: A Field Research", Innovative Marketing, Vol. 6, Issue 2, pp. 43 - 47.

Kozar, Joy M (2010), "Socially Responsible Knowledge and Behaviours: Comparing Upper-vsLower Classmen", College Student Journal, Vol. 44, No. 2.

Kurz, Tim (2002), "The Psychology of Environmentally Sustainable behavior: Fitting Together the Pieces of Puzzle", Analyses of Social Issues and Public Policy, Vol. 2, No. 1, pp. 257 - 278. http://dx.doi.org/10.1111/j.1530-2415.2002.00041.x.

Larijani, Maryam and Yeshodhara, K. (2008), "An Empirical Study of Environmental Attitudes among Higher Primary School Teachers of India and Iran", Journal of Human Ecology, 24 (3), pp. $195-200$.

Laroche, Michel; Bergeron, Jasmin and Forleo, Guido Barbaro (2001), "Targeting Consumers Who are Willing to Pay More for Environmentally Friendly Products", Journal of Consumer Marketing, Vol. 18, No. 6, pp. 503 - 520. http://dx.doi.org/10.1108/EUM0000000006155.

Lau, Teck-Chai (2010), "Towards Socially Responsible Consumption: An Evaluation of Religiosity and Money Ethics", International Journal of Trade, Economics and Finance, Vol. 1, No. 1, pp. $32-35$.

Lee, Kaman (2009), "Gender Differences in Hong Kong Adolescent Consumers' Green Purchasing Behaviour", Journal of Consumer Marketing, 26/2, pp. 87 - 96. http://dx.doi.
Characterizing and Profiling Global 
Gupta, K.

Singh, N. org/10.1108/07363760910940456.

Leigh, James H., Murphy, Patrick E. and Enis, Ben M. (1988), “A New Approach to Measuring Socially Responsible Consumption Tendencies", Journal of Macromarketing, pp. 5-20.

Luchs, Michael G. and Mooradian, Todd A. (2012), "Sex, Personality and Sustainable Consumer Behaviour: Elucidating the Gender Effect", Journal of Consumer Policy, 35, pp. 127 - 144. https://dx.doi.org/10.1007/s10603-011-9179-0.

Maloney, M. P. and Ward, M. P. (1973), "Ecology: Let's Hear from the People. An Objective Scale for the Measurement of Ecological Attitudes and Knowledge", American Psychologist, 28, pp. 583 - 586. http://dx.doi.org/10.1037/h0034936.

McCarthy and Shrum (1994), "The Recycling of Solid Wastes: Personal and Cultural Values and Attitudes about Recycling as Antecedents of Recycling Behavior," Journal of Business Research, Vol. 30, pp. 53 - 62. http://dx.doi.org/10.1016/0148-2963(94)90068-x.

McCright, Aaron M. (2010), "The Effects of Gender on Climate Change Knowledge and Concern in the American Public", Population and Environment, 32, pp. 66 - 87. http:// dx.doi.org/10.1007/s11111-010-0113-1.

Mondejar-Jimenez, J. A., Cordente-Rodriguez, M., Meseguer-Santamaria, M. L. and GazquezAbad, J. C. (2011), "Environmental Behavior and Water Saving in Spanish Housing", International Journal of Environmental Research, 5(1), pp. 1 - 10.

Mostafa, Mohamed M. (2007), "Gender Differences in Egyptian Consumers' Green Purchase Behaviour: The Effects of Environmental Knowledge, Concern and Attitude", International Journal of Consumer Studies, 31, pp. 220 - 229. http://dx.doi.org/10.1111/ j.1470-6431.2006.00523.x..

Muderrisoglu, H. and Altanlar, A. (2011), "Attitudes and Behaviors of Undergraduate Students toward Environmental Issues", International Journal of Science and Technology, 8 (1), pp. 159 - 168. http://dx.doi.org/10.1007/BF03326205.

Nathaniel, Lindsay Carolyn Tamara (2011), "What Affects Environmentally Sustainable Behaviour? A Case Study of Visitors to Whistler BC", (Master of Arts Thesis) The Faculty of Graduate Studies (Resource Management and Environmental Studies) The University of British Columbia.

https://circle.ubc.ca/bitstream/handle/2429/35011/ubc_2011_fall_nathaniel_lindsay. pdf? sequence $=1$.

Oikonomou, Stefanos; Drosatos, George; Papadopoulos, Theocharis and Oikonomou, Maria (2009), "Investigate via Internet the Consumer's Willingness to Pay for the sake of Environment protection", $2^{\text {nd }}$ International Scientific conference titled "Energy and Climate Change" of the PROMITHEAS Network. http://polis.ee.duth.gr/dros/files/ Promitheas1.pdf.

Owen, Ann L. and Videras, Julio (2006), "Civic Cooperation, Pro-Environment Attitudes, and Behavioral Intentions", Ecological Economics, 2006, Vol. 58, Issue 4, pp. 814 - 829. https://dx.doi.org/10.1016/j.ecolecon.2005.09.007.

Ozkan, Yasemin (2009), "The Effect of Some Demographic Characteristics of Turkish Consumers Socially Responsible Consumption Behaviours", World Applied Sciences Journal, 6 (7), pp. 946 - 960.

Pal, Yesh and Davar, S. C. (2001), "Meta-Analysis in Research: An Introduction”, Chapter in "Research Methodology in Management Theory and Case studies" by Arya, P. P. and Pal, Yesh, Deep and Deep Publications Pvt. Ltd., New Delhi, pp. 621 - 631.

Peattie, Ken (1995), "Environmental Marketing Management-Meeting the Green Challenge", Pitman Publishing, London.

Pickett, Gregory M., Kangun, Norman and Grove, Stephen J. (1993), "Is There a General Conserving Consumer: A Public Policy Concern", Journal of Public Policy and Marketing, Vol. 12, No. 2, pp. $234-243$.

Riezenstein, Richard C., Hills, Gerald E. and Philpot, John W. (1974), "Willingness to Pay for Control of Air Pollution: A Demographic Analysis", in 1974 Combined Proceedings, Ronald C. Curhan (Ed.), AMA, Chicago, pp. $323-328$.

Journal of Technology Management for Growing Economies, Volume 8, Number 1, April 2017 
Rikner, Amanda (2010), "Waldorf Teachers and Environmental Issues - Behavior, Values, Attitudes and Feelings of Responsibility", School of Education, Psychology and Sport Science, Master Course in psychology, 30, pp. $1-25$.

Roberts, James A. (1995), "Profiling Levels of Socially Responsible Consumer Behavior: A Cluster Analytic Approach and Its Implications for Marketing", Journal of Marketing Theory and Practice, Fall 1995, pp. 97 - 117. http://dx.doi.org/10.1080/10696679.1995. 11501709 .

Roberts, James A. (1996), "Green Consumers in the 1990s: Profile and Implications for Advertising", Journal of Business Research, 36, pp. 217 - 231. http://dx.doi. org/10.1016/0148-2963(95)00150-6.

Roberts, James A. and Bacon, Donald R, (1997), "Exploring the Subtle Relationships between Environmental Concern and Ecologically Conscious Consumer Behavior", Journal of Business Research, 40, pp. 79 - 89. https://dx.doi.org/10.1016/S0148-2963(96)00280-9.

Roper, Organization (1990), "The Environment: Public Attitudes and Individual Behaviour", Commissioned by S.C. Johnson and Son, Inc.

Roper, Organization (1992), "Environmental Behaviour North America: Canada, Mexico, United States", Commissioned by S.C. Johnson and Son Inc.

Savita, Ubba and Kumar, Naresh (2010), "Consumer Attitude towards Environment-Friendly Products: A Comparative Analysis", The IUP Journal of Marketing Management, Vol. IX, Nos. 1 \& 2, pp. $88-96$.

Schahn, J. and Holzer, E. (1990), "Studies of Individual Environmental Concern: The Role of Knowledge, Gender, and Background Variables", Environment and Behaviour, 22, pp. 767 - 786. http://dx.doi.org/10.1177/0013916590226003.

Schiffman, Leon G. and Kanuk, Leslie Lazar (1997), "Consumer Behavior", Sixth Edition, Prentice-Hall of India Private Limited, New Delhi, pp. 1 - 666.

Schwepker, Charles H. and Cornwell, Bettina T. (1991), "An Examination of Ecologically Concerned Consumers and Their Intention to Purchase Ecologically Packaged Products", Journal of Public Policy and Marketing, Vol. 10(20), pp. 71 - 101.

Shanka, Tekle and Gopalan, Gabriel (2005), "Socially Responsible Consumer Behavior Higher Education Students' Perceptions", Working Paper, ANZMAC 2005 Conference: Corporate Responsibility, pp. $102-107$.

Shetzer, Larry; Stackman, Richard W., and Moore, Larry F. (1991), "Business Environment Attitudes and the New Environmental Paradigm", Journal of Environmental Education, 22, pp. 14 - 21. http://dx.doi.org/10.1080/00958964.1991.9943057.

Shobeiri, A. M., Omidvar, B. and Prahallada, N. N. (2006), "Influence of Gender and Type of School on Environmental Attitude of Teachers in Iran and India", International Journal of Science and Technology, 3 (4), pp. 351 - 357. http://dx.doi.org/10.1007/BF03325944.

Shrum, L.J., McCarthy, John A. and Lowrey, Tina M. (1995), "Buyer Characterstics of the Green Consumer and Their Implications for Advertising Strategy", Journal of Advertising, Vol. XXIV, pp. 71 - 82. http://dx.doi.org/10.1080/00913367.1995.10673477.

Singh, Narendra (2009), "Exploring Socially Responsible Behaviour of Indian Consumers An Empirical Investigation", Social Responsibility Journal, Vol. 5, No. 2, pp. 200 - 211. http://dx.doi.org/10.1108/17471110910964487.

Singh, Narendra and Gupta, Karnika (2011), "Students as Responsible Consumers - Agents for Social Change", HSB Research Review, Vol. 2, No. 2, pp. 69 - 75.

Singh, Narendra and Gupta, Karnika (2012), "Green Consumption - A Sustainable Global Opportunity", Research Review: A Journal of Commerce and Management Association of India (CMAI), Vol. 1, First Issue, pp. 1 - 14.

Singh, Narendra and Gupta, Karnika (2013), "Environmental Attitude and Ecological Behaviour of Indian Consumers", Social Responsibility Journal (Accepted for Publication), Vol. 9, Issue 1. http://dx.doi.org/10.1108/17471111311307787.

Steg, Linda and Vlek, Charles (2009), "Encouraging Pro-Environmental Behaviour: An

Characterizing and Profiling Global 
Gupta, K.

Singh, N.
Integrative Review and Research Agenda”, Journal of Environmental psychology, 29, pp. 309 - 317. https://dx.doi.org/10.1016/j.jenvp.2008.10.004

Stern, Paul C. (2000), "Toward a Coherent Theory of Environmentally Significant Behavior", Journal of Social Issues, Vol. 56, No. 3, pp. 407 - 424. https://dx.doi.org/10.1111/00224537.00175.

Stern, Paul C. (2005), “Understanding Individual's Environmentally Significant Behavior”, ELR News and Analysis, 35 ELR 10785 - 10790.

Straughan, Robert D. and Roberts, James A. (1999), "Environmental Segmentation Alternatives: A Look at Green Consumer Behavior in New Millennium", Journal of Consumer Marketing, Vol. 16, No. 6, pp. 558 - 575. http://dx.doi.org/10.1108/07363769910297506.

Tan, Booi-Chen; Lau, Teck-Chai (2009), "Examining Sustainable Consumption Patterns of Young Consumers: Is There a Cause for Concern?" Journal of International Social Research, Vol. 2, Issue 9, pp. $465-472$.

Tanner, Carmen (1999), "Constraints on Environmental Behaviour", Journal of Environmental Psychology, 19, pp. 145 - 157. https://dx.doi.org/10.1006/jevp.1999.0121.

Tanner, Carmen and Kast, Sybille Wolfing (2003), "Promoting Sustainable Consumption: Determinants of Green Purchases by Swiss Consumers", Psychology and Marketing, Vol. 20(10), pp. 883 - 902. http://dx.doi.org/10.1002/mar.10101.

Taskin, O. (2009), "The Environmental Attitudes of Turkish Senior High School Students in the Context of Postmaterialism and New Environmental Paradigm", International Journal of Science Education, 31, pp. 481 - 502.

Tilikidou, Irene and Delistavrou, Antonia (2007), "The Ecological Consumer Behaviours in Greece: Ten Years of Research", Minutes $5^{\text {th }}$ International Congress' New Horizons in Industry and Business - NHIBE 2007, Rhodes 30-31/8, pp. 476 - 486.

http://eureka.lib.teithe.gr:8080/bitstream/handle/10184/797/ECCB_TD.pdf.

Tindall, D. B., Davies, Scott and Mauboules, Celine (2003), "Áctivism and Conservation Behavior in an Environmental Movement: The Contradictory Effects of Gender", Society and Natural Resources, 16, pp. 909 - 932. http://dx.doi.org/10.1080/716100620.

Torgler, Benno and Garcia-Valinas, Maria A. (2007), "The Determinants of Individuals' Attitudes towards Preventing Environmental Damage", Ecological Economics, Vol. 63(23), pp. 536-552. https://doi.org/10.1016/j.ecolecon.2006.12.013.

Triandis, H. C. (1993), "Collectivism and Individualism as Cultural Syndromes", Cross-Cultural Research, 27, pp. $155-180$.

Uitto, Anna; Juuti, Kalle; Lavonen, Jari and Meisalo, Veijo (2004), "Who is Responsible for Sustainable Development? Attitudes to Environmental Challenges: A Survey of Finnish $9^{\text {th }}$ Grade Comprehensive School Students", Current Research on Mathematics and Science Education, Department of Applied Sciences of Education, University of Helsinki, Research Report 253, pp. 80 - 102. http://roseproject.no/network/countries/finland/fin-uitto-2003. pdf.

Urban, Jan and Zverinova, Iva (2009), "What are the Determinants of Environmentally Significant Behavior in the Czech Republic?" CUEC Working Paper, pp. 1- 17.

Usui, Midori Aoyagi (2001), "How Individual Values Affect Green Consumer Behavior? Results from a Japanese Survey", Global Environment Research, 5, pp. 97 - 105.

Usui, Midori Aoyagi; Vinken, Henk and Kuribayashi, Atsuko (2003), "Pro-Environmental Attitudes and Behaviors: An International Comparison", Human Ecology Review, Vol. 10, No. 1 , pp. $23-31$.

Uzzell, David and Rathzel, Nora (2009), "Changing Relations in Global Environmental Change", Global Environmental Change, 19 (3), pp. 326-335. https://dx.doi.org/10.1016/j. gloenvcha.2009.05.001.

Verma, Nandita (2009), "Religion: A Saviour for Environment with Particular Emphasis on Hinduism" Hindu Today, Issue No.19, published by Panna Vekaria, Vascroft Estate, 861 Coronation Road, park Royal, London.

Journal of Technology Management for Growing Economies, Volume 8, Number 1, April 2017 
http://www.iitk.ac.in/infocell/announce/convention/papers/Context $\% 20$ and $\% 20$ Human $\% 20$ Resource-04-Nandita\%20Verma.pdf.

Vinning, Joanne and Ebreo, Angela (1992), "Predicting Recycling Behaviour from Global and Specific Environmental Attitude and Changes in Recycling Opportunities", Journal of Applied Psychology, 22(20), pp. 1580 - 1607. https://dx.doi.org/0.1111/j.1559-1816.1992. tb01758.x.

Wagh, Sanjay N. (2010), "Content Analysis of Dissertations Submitted in Library and Information Science during 1993 - 2009”, Research Analysis and Evaluation, Vol. I, Issue 14 , pp. $20-21$.

Walton, D., Thomas, J. A. and Dravitzki, V. (2004), "Commuters' Concern for the Environment and Knowledge of the effects of Vehicle Emissions", Transportation Research Part D, 9, pp. 335 - 340. https://dx.doi.org/10.1016/j.trd.2004.04.001.

Webb, Deborah J., Lois, A. Mohr and Katherine, E. Harris (2008), "A Re-Examination of Socially Responsible Consumption and its Measurement", Journal of Business Research, 61, pp. $91-98$.

Webster, Frederick E. Jr. (1975), "Determining the Characterstics of the Socially Conscious Consumer", Journal of Consumer Research, Vol. 2, pp. 188 - 196.

Xiao, Chenyang and Hong, Dayong (2010), "Gender Differences in Environmental Behaviors in China", Population and Environment, 32, pp. 88 - 104.

Young, Raymond De (2000), "Expanding and Evaluating Motives for Environmentally Responsible Behavior", Journal of Social Issues, Vol. 56, No. 3, pp. 509 - 526.

Young, William; Hwang, Kumju; McDonald, Seonaidh and J. Oates, Caroline (2010), "Sustainable Consumption: Green Consumer Behaviour when Purchasing Products", Sustainable Development, 18, pp. 20 - 31. https://dx.doi.org/10.1002/sd.394.

Yuksel, Cenk Arsun (2009), "Relationship among Socially Responsible Consumption Behavior, Anxiety, Values and Moral Philosophies", 2 (1), pp. 1 - 54.

Zelezny, Lynnette C., Chua, Poh-Pheng and Aldrich, Christina (2000), "Elaborating on Gender Differences in Environmentalism", Journal of Social Issues, Vol. 56, No. 3, pp. 443 - 457. https://dx.doi.org/10.1111/0022-4537.00177.

\section{WEBSITES}

www.businessdictionary.com

http://www.businessdictionary.com/definition/demography.html.

www.ecolabelindex.com

http://www.ecolabelindex.com/glossary/\#G

www.enviro-news.com

http://www.enviro-news.com/glossary/green_products.html

www.en.wikipedia.org

http://en.wikipedia.org/wiki/environmental_knowledge.
Characterizing and Profiling

Global 